\title{
SIX NORMATIVE PRINCIPLES FOR THE CONTRACTING-OUT DEBATE
}

\author{
CHARLES T. GOODSELL \\ Virginia Polytechnic Institute and State University
}

\begin{abstract}
Six normative principles are developed for consideration in the debate as to when and how government should directly administer its activities versus contract them out. These differ from the inherently governmental and economic efficiency criteria commonly espoused. The principles are inspired by the purposes of government stated in the Preamble to the Constitution and are developed according to Friedrich's concept of public administration as a disciplined taking of measures. Even though illustrative rather than comprehensive, the principles collectively show how public administration has moral, legal, and economic obligations.
\end{abstract}

Keywords: contracting; outsourcing; direct administration; normative theory; preamble to the constitution; Carl Friedrich

We, the People of the United States, in order to form a more perfect Union, establish Justice, insure domestic Tranquility, provide for the common defence, promote the general Welfare, and secure the Blessings of Liberty to ourselves and our Posterity, do ordain and establish this CONSTITUTION for the United States of America.

The debate as to how far government should go in contracting out its work to private parties has tended to move in two directions. The first is a legally oriented discussion of what is inherently governmental. The crux of this doctrine as it has developed in recent years is that all matters not in the inherently governmental category are appropriate candidates for outsourcing. The category's definition may be summarized as the exercise of discretion in applying federal authority to bind the United States, take

AUTHOR'S NOTE: Dedicated to the memory of an inspiring former teacher, Carl J. Friedrich. 
diplomatic or military action, conduct judicial proceedings, manage contracts, significantly affect the life, liberty, or property of private persons, and determine or control employees and property of the United States (Federal Activities Inventory Reform [FAIR] Act of 1998, sec. 5).

The second direction in which the contracting-out debate has moved is a series of criteria that are intended to promote efficiency as practiced in industry. Numerous sets of make-or-buy criteria are mentioned in the literature, stated in terms of when buying is best. Steven Kelman (2002) offers seven: "the more precisely a task or result can be specified in advance," "the more performance can be evaluated after the fact," "the more competition there is among potential providers," "the less the activity is core to the agency's mission," "the more government faces surges and ebbs in demand for the product or service," "the more private contractors have an easier time hiring people with skills the government needs," and "the more there are economies of scale in production" (pp. 305-308).

These two kinds of guidelines on what should be contracted out are useful and have much to offer. However, they lack two qualities. One is that they are conceptually biased in one direction-in favor of outsourcing and against direct administration by government. The inherently governmental doctrine is minimalist in that it identifies only the few things government must do itself, leaving all else to the possibility of private provision. Even within that circumscribed area, it prohibits outsourcing only in the exercise of discretion, not the implementation of what is decided. As for the make-buy criteria, they are phrased in terms of when it is better to contract out, not carry on activities in house. Elsewhere, I experiment with reversing the warrant, that is, asking when it is better for government to use its own personnel (Goodsell, 2004).

The second shortcoming of these approaches to the subject is that they are focused on legal and economic abstractions rather than the nature of the political order. The political order in the United States is that of a constitutional republic. It was a novel order when created two centuries ago and remains today a model admired around the world. It seems almost axiomatic that the fundamental values of this order should also shape such a key matter as who does the government's work. In this sense of the word, normative principles are needed as well for the contracting-out debate.

In this article, I develop six such principles. They are regarded as in no way final or complete, nor do they seek to chart generalized minima or maxima for the proper reach of either direct or indirect administration. Rather, they are offered as examples of policy-specific guidelines that spring from our fundamental values yet apply to today's public problems. 
The springboard for this analysis is the Preamble to the Constitution of the United States. It gives six purposes for the new national government. For each of these purposes, I develop one principle for the contracting-out debate. Although of course the Constitution created only the federal government, all of the Preamble's purposes, save the first and fourth, apply to state and local governments as well.

The heart of my argument is that governments, not contractors, should undertake functions that fall under the Preamble's purposes when the nature of the task is such that the work must be especially well carried out and under full control of responsible authorities. This article identifies specific administrative domains where I argue this to be true. My reasoning is based on a concept from the political science literature known as the disciplined taking of measures. The matters selected for consideration are taken from live issues currently in the public discourse and hence are germane to today's contracting-out debate.

\section{GOUVERNEUR MORRIS AND CARL FRIEDRICH}

The writings of two individuals are central to these normative principles. Morris was on the Pennsylvania delegation to the Constitutional Convention, where he was a key member of the Committee on Style. Known as a man who enjoyed private life as much as public, one biographer describes him as "the rake who wrote the Constitution" (Brookhiser, 2003).

Morris personally wrote the Preamble to the Constitution, quoted at the head of this article. His text was adopted unanimously without debate or alteration. Being a nationalist, Morris used the opening words "We, the People of the United States" instead of an earlier draft's "We the people of the States." He also determined the purposes for which the Constitution was adopted. Three of these were derived from the Articles of Confederation; according to its Article 3, "the said states hereby severally enter into a firm league of friendship with each other for their common defence, the security of their liberties and their mutual and general welfare" (Jensen, 1966, p. 263).

Over the years, the courts have assumed the Preamble is not legally binding. Scholars tend to ignore it except for the philosophical implications of "We the People" (e.g., Catlow, 2005). Yet this stirring long sentence, with its cadence and alliteration, has become immortal as an American credo. School children once memorized it, along with the second paragraph of the Declaration of Independence and the Gettysburg Address. It stands today as one of the most compelling articulations 
extant of the ends of American government and is the expression of the political order on which this analysis rests.

This analysis also rests on another author's work. Friedrich was long a professor of government at Harvard University and famous for his broad and creative treatments of comparative constitutional government. He saw bureaucracy as the core of modern government, and one concept he used to examine it was the taking of measures. This refers to the concrete, daily acts that officials perform in situations they face to meet particular challenges raised for the political order. Such challenges may range from a pending neo-Nazi rally or abused child case to deep social problems such as racism or overarching threats such as terrorism. Generally speaking, responses to such matters take place within the public administration, Friedrich notes, although other segments of government handle them as well, along with the making of rules and settling of disputes. An important point for us is Friedrich's (1963) underlying premise that when meeting challenges to the political order, the measures taken should subscribe to and be derived from the fundamental values, interests, and beliefs of that order.

A second feature of Friedrich's notion is that when especially severe, sudden, or dangerous challenges to the public order are being addressed, the taking of measures must have a high degree of what he calls discipline. This incorporates four traits. They are objectivity, a personal disinterestedness that accompanies commitment to the agency mission and political order; discretion, the capacity to keep confidences when the particular situation requires it; precision, or accuracy in taking exactly the right measure to fit the challenge confronted; and consistency, the need to meet identical challenges similarly and thus achieve predictability and equity. Ideally, these traits are learned initially through socialization into the organization and later on become a habit of self-discipline on the part of the measure taker. The installed presence of such discipline in the public servant serves the polity well in trying circumstances when much is at stake and when time is short. Friedrich goes on to stress that exaggerated manifestations of any of the traits can also become a liability or even a threat to the order's values.

I turn now to each of the six grand purposes of the U.S. constitutional order as set forth in the Preamble. They are considered in the sequence given there. From each I select a specific issue from which I derive a normative principle on contracting out. In accord with Friedrich's scheme, I consider in each case how the criteria of a disciplined taking of measures apply. 


\section{FORM A MORE PERFECT UNION}

By seeking a more perfect union, the founders were calling for a more effective national framework of governance than that provided by the Articles of Confederation. The national government was to be not a collectivity of states but a sovereign unto itself. Congress was given several powers, including those of taxation, regulation, and raising armies. To use these powers, national bureaucracies had to be established. Even though public administration was not as such mentioned in the Constitution, ample evidence exists it was anticipated by the framers (Beach et al., 1997).

The union's three first departments were State, Treasury, and War. They took on missions to achieve the goals anticipated by the new political order, such as forming diplomatic ties with other nations, establishing the public credit, and facilitating westward expansion. By the late 19th century, several federal entities, such as the army, navy, Civil Service Commission, Interstate Commerce Commission, Agriculture Department, and post office, demonstrated considerable institutional professionalism in pursuing their missions (Carpenter, 2001; Skowrenek, 1982).

Today, the American administrative state is tremendously larger and more complex, with a prime source of that complexity being heavy reliance on indirect administration via contracts. One would hope that this subsequent development does not detract from the capacity of federal agencies to carry out their missions and hence continue pursuance of a more perfect union. To do so, agencies would at the very least need to be able to control the matters necessary for the execution of their missions. That Kelman's (2002) fourth criterion favors not outsourcing core mission activities seems to support this standard. Two aspects of in-house mission control are particularly germane: the maintenance of sufficient expertise to interact responsibly with contractors and care in delegating the management task to contractors.

\section{MISSION EXPERTISE}

Successful mission fulfillment depends on the professional expertise of the men and women who work in the organization. If technical competence in the mission's work is possessed not by the agency but external personnel, the agency becomes dependent on private organizations in pursuit of the public interest. As James Colvard (2003, 2004) has noted, a full understanding of substantive complexities is necessary in 
house to define problems thoughtfully, assess the realism of solutions proposed, and evaluate the outcomes achieved, whether produced by contractors or not. Moreover, sufficient internal technical talent ought to be available to mediate and inform continuous dialogue between agency managers on the one side and contractor personnel on the other. This is particularly true for complex information technology installations and new weapons development. In Friedrich's formulation, this is a way to ensure that the criteria of objectivity, discretion, precision, and consistency are sufficiently incorporated into the agency's operations. Instances sometimes cited when a lack of these attributes led to severe contracting breakdowns are the Environmental Protection Agency's Superfund program and NASA's Challenger and Columbia disasters (Kettl, 1993; Roberts, 2004).

\section{MISSION INTEGRATION}

Secondly, the achievement of adequate mission execution rests on sufficient control by the agency of the work being done in its behalf. An inherent attribute of indirect administration is that it loosens that control. The issue is intensified when successive layers of subcontractors multiply the distance between responsible authorities and actual operations. The problem is worsened in an added way when agency management functions are themselves contracted out, as in drafting regulations and memoranda, recording decisions, writing reports, and responding to congressional inquiries.

Yet another order of attenuation is reached when contractors do all the managing related to the mission. The Department of Energy, a radically outsourced organization with 6 times as many people employed outside its walls than in, has for years been criticized by the General Accounting Office (GAO) for weak monitoring of its contracts to operate and maintain the 30 research laboratories and nuclear facilities within its domain. Management contracts with Bechtel, Westinghouse, Lockheed, the University of California, and other entities are awarded noncompetitively, extended every 5 years, and virtually cost-reimbursable (GAO, 1997). Spy scandals, security lapses, and safety problems at the Los Alamos National Laboratory-operated for years by the University of California - caused the Department of Energy to seek bids from three corporate-university teams to take the lab over, using higher management fees and improved incentives as bait. The winning team consisted of the University of California, together with Bechtel, BWX Technologies, and 
the Washington Group International (Broad, 2005; Weiss \& Pincus, 2005). Our first principle for the contracting-out debate

1. Command of mission execution by agencies must not be compromised by contracting out.

\section{ESTABLISH JUSTICE}

Although the crown's economic exploitation of its North American colonies was abhorrent to 18th century American nationalists, they were at the same time proud of possessing the legal rights of Englishmen. It is thus not surprising that the Founding Fathers laid the basis in the Constitution for an independent judiciary and added to it later a Bill of Rights.

Today, many aspects of the administration of justice are performed in the United States by private parties, such as legal representation, bail bonding, and community service. The work of the courts themselves, however, is usually considered properly governmental, and this point is incorporated in the FAIR Act. With respect to criminal proceedings, the logic here is that crimes are offenses against the state, hence its officers must be the ones to seek redress.

Criminal punishment, too, is usually considered a state matter, for the same reason. Then, too, humane and legal reasons bear on the matter. The penitentiary is a total institution whose inmates are continuously captive. They are concentrated into small spaces removed from external scrutiny and subject to internally administered discipline. Some argue that the way government acts in this situation truly indicates how society balances state sovereignty against individual dignity. Hence, one can argue, lengthy incarceration must live up to all four of Friedrich's criteria of objectivity, discretion, precision, and consistency. In 1986, the American Bar Association seemed to agree when it took the position that government must take direct responsibility for imprisonment of criminals and not turn this function over to private industry (Shichor, 1995).

At the federal level of government, outsourcing of prison management is confined to detention centers and halfway houses. At the local level, some jails and juvenile facilities are contracted out. It is at the state level where privatization of long-term imprisonment has flourished. Since the 1980s, several states have signed contracts with private prison companies 
such as the Correction Corporation of America to operate their penitentiaries. Defenders of the practice argue it saves taxpayer dollars and provides more management innovation and flexibility. Critics warn that by linking incarceration to profit seeking, money will be saved by hiring poorly trained staff and cutting inmate programs. Empirical studies on the subject show that cost and program differences between state-run and privatized facilities are in actuality quite modest (GAO, 1996; Hatry, Brounstein, \& Levinson, 1993; Pratt \& Maahs, 1999).

The principal issue at stake appears, then, not management improvement via contracting out but the solemn duty of government to ensure to the maximum extent possible that the sensitive relationship between power and humanity inherent in long-term imprisonment adhere as closely as possible to the values of the political order:

2. Lengthy incarceration of individuals should be administered by officers of the state.

\section{INSURE DOMESTIC TRANQUILITY}

One of the most precious gifts of domestic tranquility is safe streets and freedom from crime. In the 18th century, this was accomplished by the village constable. Since 1829, the world model for fighting crime has been the professional police force that protects public safety as a public good. In the 1980s, this model came under siege as urban crime rates rose even as police resources were cut back. Fortunately, in the 1990s rates of violent crime decreased, but after 9/11 the threat of terrorism introduced new uncertainties for domestic tranquility.

During the past quarter century, a burgeoning private security industry has come into being. An estimated two million private security employees work at American corporate offices, retail stores, public buildings, military bases, schools, shopping centers, and residential communities. Thousands more are stationed at nuclear plants, public utilities, oil pipelines, ports, bridges, and tunnels. By comparison, only about 800,000 sworn officers are employed by the nation's governmental law enforcement agencies (Wilson, 2004).

How far should privatization of the public safety function go? Friedrich would no doubt contend that assurance of realistic degrees of public safety is a fundamental tenet of the political order. He would furthermore regard the uniformed officer on the beat as an important taker of measures. Every day this person, while wearing the badge of law keeper, makes discretionary, on-the-spot decisions that affect citizens in 
dramatic ways. Hence, this public servant becomes the community's prime face of public authority. If that face presents civility and reasoned judgment, public trust obtains; if not, it deteriorates quickly.

The employees of private security firms do not labor under this stringent standard. Private security personnel represent not the community but a company. They see their duty as keeping prowlers away from factories and loiterers away from malls, not building the public trust. Furthermore, studies show that private security personnel tend to be poorly paid and trained. Their backgrounds are often not checked. Turnover rates are high. Unlike the strict regulation of private guards found in Europe, few states in the United States license security firms or set standards for their employees (Johnston, 1992; Rothman, 2004).

Thus, bestowing private guards with an aura of authority has its troublesome aspects. Yet in light of the enormous reliance placed on private security firms in this country and the limited resources available to fund public law enforcement, it seems unrealistic to expect a major restructuring of the American public safety function. But this does not mean we cannot draw a line between appropriate roles for the public and private sectors in carrying it out.

The question is when we are willing to permit the private security guard to ensure domestic tranquility and when we want the sworn public officer to do so. The security guard seems adequate when the safety of private property is mainly at stake or in situations where the general public is mostly absent. Thus, private guarding of factories, nuclear plants, military bases, private office buildings, and gated communities seems quite acceptable, as does the protection at night of government buildings, schools, and public infrastructure facilities. However, in urban public places such as streets and parks and in government buildings and public schools during business hours, it is important to have sworn officers constitute the principal law enforcement presence.

Hence, at least two guidelines are recommended. One is that uniformed private guards bearing side arms should be kept off public streets. A Rand survey published in the 1970 s found that $48 \%$ of private security personnel are armed while on duty (Kakalik \& Wildhorn, 1977). In St. Louis, armed police volunteers regularly conduct street patrols (Johnston, 1992). In Texas, members of a deputized private police force known as the Texas Special Rangers (not to be confused with the Texas Rangers, an official state police force) possess full arrest and armscarrying powers anywhere in the state except on highways. Interestingly, many members of this group operate their own private security companies (O'Toole, 1978). 
A further needed step is to apply tighter rules to police officers who moonlight. The legal powers of off-duty police officers are generally not suspended while being employed privately. Some cities do not even require them to remove their badges and firearms or change uniforms while doing such work. When this occurs, significant public damage can be done if citizens realize what is going on or the quality of law enforcement falters, as may easily happen when officers are burdened with excess fatigue by working beyond their regular hours (Stewart, 1985).

3. In public places, armed enforcement of the law should be carried out by sworn officers fully alert to their duties.

\section{PROVIDE FOR THE COMMON DEFENSE}

Providing for the common defense, called for in the Articles of Confederation and the Constitution's Preamble, is clearly an elemental function of the state-probably the most elemental. Without a strong national defense, the safety of the state itself is in jeopardy. In this day of preemptive invasions and international terrorism, an adequate offense and defense mounted by state forces seems necessary, and indeed the FAIR Act refers to military action generally. In Friedrich's logic, this is because the very existence of the political order is at stake. It is not surprising that the Weberian characteristics of an objective, discrete, precise, and rule-based bureaucracy permeate military organization.

Yet privatization has extensively invaded the military realm. In recent decades, a new commercial business has emerged, the private military industry. It began in its modern form in apartheid Africa and has since spread to trouble spots around the globe. International military firms provide logistical support to armed forces and also perform protection, training, consulting, and planning services. Some companies, notably Sandline International, actually engage in combat under contract (Singer, 2003).

The occupation and attempted reconstruction of Iraq has been undertaken with heavy involvement by more than 100 contractors. Leading examples are KBR (Kellog, Brown \& Root, a Halliburton subsidiary), Bechtel, CACI International, Custer Battles, Titan Corporation, and Blackwater USA. These firms have signed billions of dollars worth of ongoing, largely open-ended, cost-reimbursable service contracts with the U.S. government. It appears that in excess of 85,000 contractor personnel work in Iraq, with more than 25,000 engaged in protective security alone. The Pentagon, CIA, and White House regard these contractors as 
absolutely essential to the war. Critics of the war allege that the real reason for so much outsourcing is to keep troop levels in Iraq as low as possible for domestic political reasons.

Uniformed military personnel knowingly risk the sacrifices of injuries and death to serve their country. In Friedrich's language, this can be translated as a profound commitment to the values, interests, and beliefs of the political order. But what can be expected from private citizens who accept employment with a contractor and enter a war zone to make money?

Many such individuals in Iraq carry out seemingly noncombatant duties such as drive trucks, feed troops, maintain oil pipelines, and rebuild power stations. Yet they do so in an environment where, every day, shots are fired and bombs go off. Others perform duties that, until the post-9/11 wars came along, were carried out only by uniformed personnel. These include guarding bases, protecting civilian officials, and escorting military convoys. In addition, contract personnel in Iraq plan street patrols, go on them as interpreters, interrogate prisoners, and disarm munitions. They often wear body armor, carry arms, and travel in Humvees. Only the left-pocket designation "DoD Civilian" or "US Contractor" may distinguish them from soldiers and Marines (Cha \& Merele, 2004).

As we all know, such work can be very dangerous. By the fall of 2005, deaths of contractor personnel exceeded 400. Between 1,000 and 2,000 had been wounded. Several have been kidnapped and well-publicized incidents of beheadings, mutilations, and the dragging of corpses through the streets and hanging them on bridges have occurred (Finer, 2005).

At least three questions emerge from this situation. One is whether these de facto civilian soldiers, with their nonmilitary motivations and sources of authority, are compatible with the unified command system necessary in war. A second consideration has to do with the conduct of armed civilians in a hostile war zone. A third issue is whether civilian workers are adequately prepared for this hostile environment.

\section{COMMAND COMPATIBILITY}

The first matter is parallel to the question raised in the more perfect union discussion about command of mission execution. Military combat requires even more integration and cohesion. Fortunately, a high proportion of contractor personnel have military backgrounds, in some cases as Green Berets or Navy Seals. This does not guarantee adequate civilian-military coordination, however. Although formally contract 
personnel are advisers or partners to military units, often their technical skills, cultural knowledge, and personal connections to high-ranking officers give them independent status. In addition, these individuals can find themselves in positions where decision-making latitude is great. An employee of CACI International states that when he performed as interrogator at the Abu Ghraib prison, he received little direction or oversight from military and CIA officers in the Joint Intelligence Interrogation and Debriefing Center that operated the facility (Cha \& Merle, 2004; McCarthy, 2004).

\section{DISCIPLINED CONDUCT}

By order of the now-defunct Coalition Provisional Authority, all contract personnel in Iraq are immune from both military and Iraqi law. This means that accountability for their actions extends only to their employers, whose corporate presence in the war zone is typically diffuse and elusive. Armed and mobile contractor groups are, like the troops themselves, capable under the tensions of war of overreacting to potentially dangerous situations. Incidents of friendly fire both from and at civilian personnel have occurred. On one occasion, Marines detained 19 civilian workers for 3 days, charging them with firing on their men. In another instance, an Army unit barred contract employees from their mess hall because they refused to disarm when eating (Merle \& Witte, 2005).

By the third year of the war, stories were surfacing of contract personnel "running loose," as in shooting Iraqi civilians under questionable circumstances. Between July 2004 and September 2005, some 122 shootings occurred while contract employees conducted guard duty, and only 3 resulted in disciplinary action. One contractor practice, known as "clearing by fire," is when convoys of company-owned vehicles proceed down streets while indiscriminately spraying bullets ahead of them.

In early 2006, contractor personnel affiliated with the State Department, riding in a convoy of three SUVs, opened fire on a taxi north of Kirkuk, killing two ethnic Kurds and injuring a third. They were taken into custody by Iraqi authorities for interrogation (Finer, 2005, 2006).

\section{ADEQUATE PREPARATION}

Although the military veterans among contract workers know in advance the hazards to be faced in a war zone, those from civilian backgrounds cannot. All employees heading for Iraq, regardless of experience, 
should receive sufficient advanced training or retraining for such an environment. However, this is usually not provided. Typically, the newly recruited security guard receives perhaps a week's preparation before going on the job. In addition, these workers may not be given adequate equipment. A former sheriff's deputy from Maryland, hired by Custer Battles as a bomb-detection dog handler, found his body armor to be substandard and firepower insufficient. Korean contract engineers working on Iraq's power grid have complained that they do not get the flak jackets and protective helmets given to American engineers (Barstow, 2004; Cha, 2005).

Persons recruited from poverty backgrounds abroad for menial contract work in Iraq can be particularly unprepared for what lays in store for them. Employment agents, working at the bottom of several tiers of subcontractors, place glowing help-wanted ads in third world newspapers. These entice recruits by offering wages that seem huge in the local economy but are drastically substandard in Iraq. The agents also "sell" these unsuspecting individuals work visas at a handsome fee (Sullivan, 2004).

In one instance, agents of KBR subcontractors hired workers in India for \$200 a month, ostensibly to do food service work in Kuwait. But on arriving in that country, they were bused without warning across the border to a military base in Iraq. There, the laborers were fed leftovers from the mess hall, given nonpotable tap water rather than bottled, and housed in tents apart from the air conditioned trailers of higher status employees. During the nights, lying in their hot tents, the workers were terrified by the sounds of gunfire and mortar rounds (Cha, 2005; Margasak, 2006).

Operating in a war zone can also be traumatic for employed Americans. A truck driver from Texas was hired by KBR to drive convoys across Iraq from a base in Kuwait. After 4 months into a 1-year hitch, he became obsessed by images of bodies along the highways and beheadings on television and opted to return home. On the way, while passing through the base contractor lounge, he noticed this hand-lettered sign posted on the wall (Spinner, 2005):

I got no medals, patches or awards

You tell your story so loved ones can hear

I've been cautioned to keep quiet my job to fear

No one knows us; we're just hurting, bleeding and dying

We're just contractors

4. Military activities in active war zones should be conducted by the armed forces and not contractors. 


\section{PROMOTE THE GENERAL WELFARE}

To the founders, "general welfare" referred to the domestic aims of government generally, not the social safety net we know today. Yet in both past and present uses of the term welfare, contracting out was and is by no means unusual. In view of this, the fifth purpose named in the Preamble inspires us less on demarcating outsourcing's limits than on making sure of its quality. When contracted supplies or services are vitally needed by the general public, a failure to deliver adequately can be a serious matter for citizens and governments alike.

This point was brought home in the summer of 2005 by the Katrina and Rita hurricanes along the Gulf Coast of the United States. In meeting such emergencies, governments themselves cannot provide the lifesustaining goods and services needed. Contractors must be called in. But the fact that lives are at stake means that Friedrich's traits of disciplined administration should apply to the contracting process.

The consensus of the political world, the media, and the general public was that the governmental response to the gulf storms and their aftermath was unacceptably poor. Part of the problem was the massive extent of the damage. Also, a series of missteps and lack of coordination occurred at all levels of government. Particular blame was laid on the Federal Emergency Management Agency (FEMA) in Washington. This agency, which had been performing well during the Clinton administration, was severely weakened during the George W. Bush years by unqualified political appointees, deep budget cuts, and absorption into the Department of Homeland Security (Schneider, 2005).

Following Katrina, unprecedented amounts of food, water, ice, shelter, transportation, and a myriad other items were needed. Congress quickly approved $\$ 62$ billion for relief. A vast amount of contracting needed to be done immediately, but FEMA was not ready. Its number of acquisition personnel was about 50 in an organization of 2,500, and an earlier audit of this staff had raised questions about its competence. Contracting-out capacity was so limited that one of FEMA's first outsourcing steps in the crisis was to hire a contractor to write contractsAcquistions Solutions, for whom many former FEMA contracting personnel worked. Although some standing contracts with qualified bidders were available to activate, these were far from sufficient. Opportunities for poor judgment, overpayment, and favoritism were exacerbated by a loosening of the rules to speed things up (Witte \& O'Harrow, 2005). 
Indeed, many troublesome contracts later came to light. Open-ended deals worth up to $\$ 100$ million each for putting up temporary housing were made with four big construction firms, namely Bechtel, CH2M Hill, Fluor, and the Shaw Group. Following criticism from GAO and others that millions were being wasted, FEMA announced it would reopen the contracts to bidding. Later, the agency reversed its position, possibly because of political connections with the Bush administration. The interests of Shaw in the matter were represented by lobbyist Joseph Allbaugh, the administration's prior FEMA director ("FEMA Abandons Pledge," 2006).

The emergency response system in the United States is a complex network of local, state, and national agencies, and improvement of its contracting processes must be multifaceted and widespread. Although reform of FEMA is and probably should be at center stage, it seems clear that outsourcing capability must be improved at all levels. A number of possibilities for moving closer to the ideal of disciplined objectivity, precision, and consistency come to mind.

One would be to create an online registry of prescreened contractors, checked for licensing, reliability, and integrity. This would happen in all expected work areas and in all regions of the country. A second step could be to grant each state and local emergency management agency a standing dollar amount of authority to make purchases from these vendors, to be triggered by a presidential declaration of emergency. Third, a greater number of standing contracts should be drawn up with large companies that could be activated in extensive disasters over wide areas. These contracts also could be prevetted and activated automatically. The model company here is Lipsey Mountain Water of Norcross, Georgia. Following a call from the Corps of Engineers, Lipsey began shipping truckloads of water to New Orleans within 24 hours of Katrina's landfall (Witte \& Babcock, 2005).

5. Governments must be continuously poised to engage in immediate and effective contracting after natural disasters.

\section{SECURE THE BLESSINGS OF LIBERTY}

The Articles of Confederation sought to secure the liberties of states. The Preamble, by contrast, secures the blessings of liberty for individuals. Moreover, in it Morris shifted liberty to the end of the list of constitutional purposes, thus inviting contemplation of its blessings for our posterity. 
The idea of liberty is of course especially treasured in the American political order. The liberty of private persons is included in FAIR's inherently governmental category. Many would argue that ensuring the rights of citizens is the purpose of the Constitution. Accordingly, the maintenance of individual liberties would seem to be a matter that must be placed in the most reliable and accountable hands possible. Usually it is, for example, with those of federal judges. But occasionally this is not the case. What follows are examples of where contractors are in charge of the liberties of Americans.

The Freedom of Information Act (FOIA) has long been a tool for giving private groups and the press the opportunity to hold government accountable. Responses to FOIA requests are no longer prepared by agency staff but by contract personnel. In another aspect of release of government information, the General Services Administration (GSA) has turned the Federal Procurement Data System over to a contractor, Global Computer Enterprises (GCE). GCE has redesigned this huge government-wide database that is entered daily by individuals and companies looking for contract opportunities. Although before GSA permitted free access to raw data in the system, now only formatted versions may now be obtained, for a fee (Lee, 2004a, 2004b).

In contractual arrangements involving the right to privacy, the FBI has abandoned its famous (or infamous?) Internet surveillance technology, once known as Carnivore. Instead, commercially available software is being used to eavesdrop on e-mail and other Internet computer traffic in the course of criminal and terrorist investigations. In an even more ominous development, the FBI is asking Internet providers themselves to conduct wiretaps on targeted customers, reimbursing them for expenses (Bridis, 2005).

Contracting out has also been involved in the dispensing of information by government. A cause celebre was created when it was discovered that Armstrong Williams, a conservative media figure, had used a public relations contract with the Department of Education to promote the president's No Child Left Behind program. Contract documents stipulated that Williams was to use his relationships with television producers to encourage them to give favorable attention to the initiative. The contract also called for evaluating journalists on how positively or negatively they reported on it (Dobbs, 2005; Kurtz, 2005).

In the aftermath of the uproar, other agencies were also found to be using public relations contracts to promote administration policies, leading the president to call for an end to such arrangements. Later, however, 
the administration rejected a GAO view that prepackaged video news releases that defended federal programs without revealing their government origins violated laws against propaganda (Lee, 2005a, 2005b).

A final example of contractor involvement in individual liberties is a statute that permits the IRS to use private collection agencies to collect unpaid income taxes from citizens. More than 30 collection companies have expressed interest in getting this business. Their compensation will be a share of the take, up to $25 \%$. Critics of the idea are concerned that by making profits proportionate to collections, such contracts encourage abusive collection techniques in pursuit of private gain, parallel to what IRS agents were once accused of doing to meet performance goals (Everson, 2003; Olson, 2003).

In conclusion, contractors and other companies screen the release of government information, sell searches of government information, make available wiretap software and use it on citizens, produce government sales pitches, and could make money by pursuing tax delinquents. Are these uses of the commercial world by government appropriate to a freedom-loving country? I do not think so.

6. Government activity that threatens the freedoms or rights of citizens should not be contracted out.

\section{CONTRACTING OUT: DOING IT RIGHT}

To supplement the inherently governmental standards embedded in statute and the make-versus-buy criteria based in economics, these pages offer six principles for the contracting-out debate that spring from the Preamble to the Constitution and follow the logic of utilizing effective direct administration when conditions warrant a high degree of discipline and accountability. These principles affirm that agencies cannot be asked to act without controlling execution of their mission; states should not delegate responsibility for maintaining human dignity within their prisons; communities should not wield force in public places except by sworn officers; when fighting wars, the nation ought not allow uncontrolled or unprepared civilians to be employed within the war zone; when natural disasters occur, government agencies must be contractually prepared to provide immediate help to citizens; and when governmental activities touch intimately on the blessings of liberty, those activities should be directly administered by accountable officials. 
In other words, contracting out has a moral dimension. It must be done right. Although adoption of these six principles would not fundamentally alter America's current mode of governing, it could lay the basis for reconsidering the long-term impacts on public values of the rush to outsource as they affect the aspirations held by We the People of the United States for our constitutional republic.

\section{REFERENCES}

Barstow, D. (2004, April 19). Security companies: Shadow soldiers in Iraq. New York Times, p. A1.

Beach, J. C., Carter, E. D., Dede, M. J., Goodsell, C. T., Guignard, R., Haraway, W. M., et al. (1997). State administration and the Founding Fathers during the critical period. Administration \& Society, 28, 511-530.

Bridis, T. (2005, January 18). FBI abandons Web surveillance technology. Roanoke Times.

Broad, W. J. (2005, December 22). California is surprise winner in bid to run Los Alamos. The New York Times, p. A28.

Brookhiser, R. (2003). Gentleman revolutionary: Gouverneur Morris, the rake who wrote the Constitution. New York: Free Press.

Carpenter, D. P. (2001). The forging of bureaucratic autonomy: Reputations, networks, and policy innovation in executive agencies, 1822-1928. Princeton, NJ: Princeton University Press.

Catlow, T. J. (2005). Constitution as executive order: The administrative state and the political ontology of "we the people." Administration \& Society, 37, 445-482.

Cha, A. E. (2005, July 1). Underclass of workers created in Iraq. The Washington Post, p. A1.

Cha, A., \& Merle, R. (2004, May 13). Line increasingly blurred between soldiers and civilian contractors. The Washington Post, p. A1.

Colvard, J. E. (2003, June). Why navy laboratories? Presentation at National Defense University, Washington, D.C.

Colvard, J. E. (2004, September 1). Stop outsourcing know-how. Government Executive, p. 80.

Dobbs, M. (2005, January 14). Education chief defends payments to pundit. The Washington Post, p. A4.

Everson, M. W. (2003, May 13). Use of private collection agencies to improve IRS debt collection. Hearing before House Subcommittee on Oversight, Committee on Ways and Means, 108th Cong., 1st Session.

Federal Activities Reform Act of 1998, P.L. 105-270, 105th Cong., 112 Stat. 2382.

FEMA abandons pledge to rebid contracts. (2006, March 25). Roanoke Times, p. 4A.

Finer, J. (2005, September 10). Contractors "run loose" in Iraq. The Washington Post, p. A1.

Finer, J. (2006, February 9). State Department contractors kill 2 civilians in n. Iraq. The Washington Post, p. A18.

Friedrich, C. J. (1963). Man and his government: An empirical theory of politics. New York: McGraw-Hill.

General Accounting Office. (1996). Private and public prisons: Studies comparing operational costs and/or quality of service (GAO/GGD-96-158). Washington, DC: Author. 
General Accounting Office. (1997). Department of Energy contract management (GAO/HR-97-13). Washington, DC: Author.

Goodsell, C. T. (2004). The case for bureaucracy: A public administration polemic (4th ed.). Washington, DC: CQ Press.

Hatry, H. P., Brounstein, P. J., \& Levinson, R. V. (1993). Comparison of privately and publicly operated corrections facilities in Kentucky and Massachusetts. In G. W. Bowman, S. Hakim, \& P. Seidenstadt (Eds.), Privatizing correctional institutions (pp. 193-212). New Brunswick, NJ: Transaction.

Jensen, M. (1966). The Articles of Confederation: An interpretation of the social-constitutional history of the American Revolution, 1774-1781. Madison: University of Wisconsin Press.

Johnston, L. (1992). The rebirth of private policing. London: Routledge.

Kakalik, J. S., \& Wildhorn, S. (1977). The private police: Security and danger. New York: Crane Russak.

Kelman, S. J. (2002). Contracting. In L. M. Salamon (Ed.), The tools of government: A guide to the new governance (pp. 282-318). Oxford, UK: Oxford University Press.

Kettl, D. F. (1993). Sharing power: Public governance and private markets. Washington, DC: Brookings Institution.

Kurtz, H. (2005, January 8). Commentor paid to push policy. The Washington Post, p. A1.

Lee, C. (2004a, August 3). Access to contract data questioned. The Washington Post, p. A15.

Lee, C. (2004b, June 8). On FOIA front, more agencies contract out. The Washington Post, p. A21.

Lee, C. (2005a, March 15). Administration rejects ruling on PR videos. The Washington Post, p. A21.

Lee, C. (2005b, October 1). GAO issues mixed ruling on payments to columnists. The Washington Post, p. A10.

Margasak, L. (2006, January 23). Workers allege Halliburton knew their water was foul. The Washington Post, p. A2.

McCarthy, E. (2004, May 17). CACI contract: From supplies to interrogation. The Washington Post, p. E1.

Merle, R., \& Witte, G. (2005, July 29). Security costs slow Iraq reconstruction. The Washington Post, p. A1.

Olson, N. E. (2003, May 13). Use of private collection agencies to improve IRS debt collection. Hearing before House Subcommittee on Oversight, Committee on Ways and Means, 108th Cong., 1st Sess.

O'Toole, G. (1978). The private sector: Private spies, rent-a-cops, and the police-industrial complex. New York: Norton.

Pratt, T. C., \& Maahs, J. (1999). Are private prisons more cost-effective than public prisons? A meta-analysis of evaluation research studies. Crime \& Delinquency, 45, 358-371.

Roberts, A. (2004). The reform bubble bursts. Public Administration Review, 64, 625-629.

Rothman, P. (2004, May 1). Are private buildings at risk in D.C.? Access Control \& Security Systems.

Schneider, S. K. (2005). Administrative breakdowns in the governmental response to Hurricane Katrina. Public Administration Review, 65, 515-516.

Shichor, D. (1995). Punishment for profit: Private prisons/public concerns. Thousand Oaks, CA: Sage.

Singer, P. W. (2003). Corporate warriors: The rise of the privatized military industry. Ithaca, NY: Cornell University Press.

Skowrenek, S. (1982). Building a new American state: The expansion of national administrative capacities, 1887-1920. Cambridge, UK: Cambridge University Press. 
Spinner, J. (2005, January 17). For one contractor: A road too hard. The Washington Post, p. A1.

Stewart, J. K. (1985). Public safety and private police. Public Administration Review, 45, 758-765.

Sullivan, K. (2004, December 9). Poor Salvadorans chase the "Iraqi dream." The Washington Post, p. A24.

Weiss, R., \& Pincus, W. (2005, May 18). Los Alamos oversight up for bid. The Washington Post, p. A15.

Wilson, D. (2004, March 30). Private Security Officer Employment Authorization Act of 2003. Hearing before House Subcommittee on Crime, Terrorism, and Homeland Security, Committee on the Judiciary, 108th Cong., 2nd Sess.

Witte, G., \& Babcock, C. R. (2005, September 13). A major test for FEMA and its contracting crew. The Washington Post, p. A1.

Witte, G., \& O'Harrow, R. (2005, September 17). Short-staffed FEMA farms out procurement. The Washington Post, p. A1.

Charles T. Goodsell is Professor Emeritus of Public Administration at the Center for Public Administration and Policy, Virginia Polytechnic Institute and State University. He has published widely in several realms, including the politics of foreign investment, the bureaucratic encounter between citizen and state, the social meanings of public architecture, the arts and public administration, and the contributions of public bureaucracy to American democracy. In 2003 he received the Dwight Waldo Award. Currently he is writing a book to be titled Mission Mystique: The Power of Purpose in Public Administration. 